\title{
Informatory o zasobie archiwalnym. Próba analizy przydatności informacyinej
}

DOI: http://dx.doi.org/10.12775/TSB.2014.019

STRESZCZEniE: W 2000 r. Naczelny Dyrektor Archiwów Państwowych wydał zalecenia dotyczące wydawania informatorów o zasobie archiwalnym. Ich celem było m.in. wprowadzenie do systemu informacji archiwalnej pośredniej pomocy informacyjnej (między przewodnikami a spisami zespołów archiwalnych), ujednolicenie ich budowy i podniesienie znaczenia w procesie wyszukiwania materiałów archiwalnych. Cel ten udało się zrealizować w części. Na podstawie przepisów można sformułować termin informator o zasobie archiwalnym. Nie udała się pełna standaryzacja informatorów. Zalecenia z 2000 r. są ogólne i niejednoznaczne. Archiwa zmieniały budowę informatorów z własnej inicjatywy. Wprowadzane modyfikacje nie zawsze były korzystne z informacyjnego punktu widzenia. Rzadko także wydawcy informatorów świadomie korzystali z narzędzi typograficznych, które mogą zwiększyć informacyjną użyteczność tych pomocy.

SŁowA KLUCzowe: informatory o zasobach archiwów w Polsce, typografia archiwalnych pomocy informacyjnych. 
W czerwcu 2000 r. Naczelny Dyrektor Archiwów Państwowych ostatecznie zdecydował się wprowadzić do archiwistyki i dziedziny archiwalnej grupę pomocy informacyjno-wyszukiwawczych, które zostały nazwane informatorami o zasobie archiwum ${ }^{1}$. Zdefiniowano je jako opracowania „o charakterze (głębi informacyjnej) pośrednim między spisem zespołów a przewodnikiem po zasobie archiwum"2. Ich przedmiotem miał być zasób jednego archiwum państwowego, choć dopuszczano możliwość publikowania samoistnych wydawniczo informatorów dla oddziałów terenowych. Opis zespołów archiwalnych, oprócz danych podstawowych (nr zespołu, jego tytuł, daty skrajne, liczba jednostek archiwalnych i metrów bieżących, stan opracowania i pomoce archiwalne), miał zawierać sumaryczne omówienie treści materiałów archiwalnych ${ }^{3}$.

Od momentu wydania zaleceń trzynaście archiwów opublikowało pomoce informacyjne, w których tytule pojawiał się zwrot „informator o zasobie archiwalnym". Pierwszym z nich było Archiwum Państwowe [dalej: AP] w Białymstoku4, ostatnim - AP w Bydgoszczy. Dwa archiwa wydały osobno informatory dla centrali i jej terenowych oddziałów (AP w Białymstoku i AP w Katowicach), jedno archiwum - tomy dla dwóch oddziałów (AP m.st. Warszawy, obecnie AP w Warszawie)5. Informatory

1 Pismo Naczelnego Dyrektora Archiwów Państwowych z 6 czerwca 2000 r. w sprawie zaleceń dotyczacych opracowania informatora o zasobie archiwum państwowego (wraz $\mathrm{z}$ Zaleceniami dotyczacymi opracowania informatora o zasobie archiwum państwowego) [online]. Warszawa: Naczelna Dyrekcja Archiwów Państwowych, 2000, 6 s. [dostęp 31 października 2014]. Dostępny w World Wide Web: http://www.archiwa.gov.pl/images/ stories/file/pdf/Pismo_6_2000.pdf.

2 Zalecenia dotyczace opracowania informatora...

3 Tamże.

${ }^{4}$ Por. J. Krochmal, Zasady opracowania informatora o zasobie archiwalnym. Na marginesie publikacji „Informator i zasobie archiwalnym”, oprac. Jerzy Szumski, Białystok 2000, Archiwum Państwowe w Białymstoku, ss. 279, „Archeion” t. 104: 2002, s. 257-259.

${ }_{5}$ Oprócz nich do wydania przygotowano w 2010 r. informator dla mławskiego oddziału warszawskiego archiwum, jednak nie doczekał się on wersji papierowej. Plik z jego wersją po składzie, jednak bez kilku informacji identyfikacyjnych (m.in. brak numeru CIP), jest dostępny w sieci, zob.: Archiwum Państwowe m.st. Warszawy Oddział w Mławie. Informator o zasobie archiwalnym, oprac. Andrzej Grochowski, Monika Kowzon-Świtalska [online]. Warszawa: Archiwum Państwowe w Warszawie, 2010, 333 s. [dostęp 31 października 2014]. Dostępny w World Wide Web: http://www.warszawa.ap.gov.pl/ publikacje/informator-mlawa.pdf. 
białostockiego archiwum doczekały się w tym czasie drugich wydań. W ten sposób przedmiotem analizy jest 17 wydawnictw ${ }^{6}$.

W artykule nie będziemy zastanawiać się nad zasadnością definiowania informatorów o zasobie archiwalnym jako nowej, odrębnej grupy archiwalnych pomocy informacyjno-wyszukiwawczych. W wypracowywanym przez dziesięciolecia systemie informacji archiwalnej w Polsce pomoce o przypisanych informatorom cechach nazywa się przewodnikami informacyjnymi ${ }^{7}$. Nie będziemy polemizowali ze wszystkimi, którzy „analogową” formę prezentacji informacji o archiwaliach uważają za anachroniczną. Rozumiemy ich stanowisko w dobie powszechnego dostępu do sieci, komputeryzacji i informatyzacji archiwów, wprowadzania do rzeczywistości wirtualnej nowoczesnych narzędzi wyszukiwania informacji o materiałach archiwalnych, które coraz częściej są także dostępne online. Nasze własne doświadczenia przekonują, że korzystanie z tradycyjnych pomocy archiwalnych ułatwia użytkownikom - szczególnie uczonym - tworzenie kompletnej listy zapytań informacyjnych, formułowanie instrukcji wyszukiwawczych, w efekcie zaś pozwala efektywnie zaspokajać indywidualne potrzeby informacyjne. Naszym celem jest analiza określonego typu publikacji o cechach serii wydawniczej z punktu widzenia przyczyn i funkcji, dla których zaczęto je wydawać.

${ }^{6}$ Pełną listę informatorów objętych analizą zob. aneks do artykułu. Informator o zasobie AP w Zielonej Górze wydany w 2003 r.: Informator o zasobie Archiwum Państwowego w Zielonej Górze, red. nauk. Z. Bujkiewicz, W. Strzyżewski (Zielona Góra 2003) nie nawiązuje do modelu wprowadzonego wytycznymi NDAP z 2000 r. Podobnie informatory o zasobie dwóch centralnych archiwów państwowych: Archiwum Akt Nowych (Informator o zasobie archiwalnym [Archiwum Akt Nowych], oprac. E. Kołodziej, współpr. W. Bieńkowska, B. Nowożycki, t. 1-2, Warszawa 2009) oraz Archiwum Głównego Akt Dawnych (Archiwum Główne Akt Dawnych w Warszawie. Informator o zasobie archiwalnym, oprac. zbior. pod red. D. Lewandowskiej, Warszawa 2008). W przypadku informatora AGAD tytuł i szata graficzna zdają się wskazywać, że wydawnictwo to należy do omawianej grupy. $\mathrm{W}$ istocie jest to drugie, rozszerzone i uzupełnione wydanie pracy Archiwum Główne Akt Dawnych. Informator o zasobie, oprac. zbior. pod red. T. Zielińskiej (Warszawa 1992). Por. Archiwum Główne Akt Dawnych w Warszawie. Informator..., s. 21.

7 Por. B. Ryszewski, Przegląd oraz systematyka pomocy archiwalnych polskich i obcych opublikowanych $w$ ostatnim ćwierćwieczu, „Archeion” t. 87: 1990, s. 12, 17. Na ten aspekt funkcjonowania informatorów w archiwalnym systemie informacyjnym zwracano również uwagę na marginesie prezentacji poszczególnych tomów. Zob. m.in. R. Degen, Przegląd piśmiennictwa archiwistycznego (część VI), „Archiwista Polski” 2004, nr 2, s. 106; tenże, Przegląd piśmiennictwa archiwistycznego (część XII), „Archiwista Polski” 2005, nr 4, s. 101. 
Chcielibyśmy, by nasze rozważania przyniosły odpowiedź na pytanie, czy wykorzystano wszystkie możliwości - zarówno w zakresie konstrukcji opisu informacyjnego, jaki i układu typograficznego, by z informatorów o zasobie archiwalnym uczynić efektywne narzędzia wyszukiwacze.

Budowany w Polsce do początku lat 90. XX w. system informacji archiwalnej przewidywał funkcjonowanie dość rozbudowanego aktywnego zbioru wyszukiwawczego ${ }^{8}$. W jego skład wchodziły inwentarze archiwalne, spisy archiwaliów (m.in. spisy zdawczo-odbiorcze), katalogi, sumariusze i repertoria archiwalne, indeksy archiwalne, spisy zespołów, kartoteki zespołów, przewodniki archiwalne (po zasobie archiwum, tematyczne, po zespołach archiwalnych), informatory o archiwach oraz opisowe archiwalne pomoce informacyjne. Pomoce te różniły się między sobą m.in. głębią informacyjną ${ }^{9}$ czy okolicznościami, w jakich były opracowywane. Przygotowanie niektórych z nich było obowiązkowe, niektórych nie. Z większości można było korzystać jedynie w pracowniach naukowych archiwów, co w oczywisty sposób ograniczało dostęp do informacji o materiałach archiwalnych.

Państwowa administracja archiwalna od lat 60. XX w. angażowała się w działalność publikacyjną, której celem było wydawanie pomocy archiwalnych, przede wszystkim przewodników po zasobach archiwów ${ }^{10}$. Charakterystyczną cechą działań w tym zakresie było niezbyt szybkie tempo opracowywania i wydawania ich drukiem ${ }^{11}$. W tej sytuacji w końcu lat 70. zaakceptowano publikowanie spisów zespołów poszczególnych archiwów, które zaczęto tytułować informatorami o zasobie archiwalnym

${ }^{8}$ Zob. m.in.: M. Gołembiowski, System informacji archiwalnej, Warszawa-Łódź 1985, s. $102-125$.

9 Głębię informacyjną rozumiemy jak Maciej Gołębiowski w 1985 r. Wg toruńskiego uczonego jest to „stopień szczegółowości informowania, zgodny ze strukturą zasobu archiwalnego", por. tamże, s. 97.

${ }^{10}$ W latach 70. XX w. Czesława Ohryzko-Włodarska pisała, że przewodniki po zasobach poszczególnych archiwów są pomocą „ocenianą bardzo wysoko przez badaczy i przez inne osoby korzystające z archiwów [...] Dają one orientację o całości posiadanych przez archiwum materiałów i stanie ich udostępniania oraz informują dość szczegółowo o zawartości poszczególnych zespołów", C. Ohryzko-Włodarska, Pomoce informacyjne w archiwach. Stan obecny i perspektywy na przyszłość, „Archeion” t. 68: 1979, s. 92.

11 Zwracali na to uwagę m.in. uczestnicy narady w sprawie opracowywania przewodników po zasobach archiwów, zorganizowanej 29 września 1975 r. w Naczelnej Dyrekcji Archiwów Państwowych, zob. M. Lewandowska, Sprawozdanie z narady w sprawie opracowania przewodników po zasobach archiwów, „Archeion” t. 64: 1976, s. 283. 
(archiwum) ${ }^{12}$. Miały one niewielką głębię informacyjną, ale pozwalały na szybsze publikowanie i aktualizowanie informacji o zasobie archiwów. Przywołane na początku artykułu pismo i zalecenia Naczelnego Dyrektora z czerwca 2000 r. miały za zadanie ujednolicić ich formułę i zawartość, a przez to podnieść wartość informacyjną ${ }^{13}$.

W zaleceniach zapisano, że informatory o zasobie archiwum państwowego w systemie informacji archiwalnej mają zająć miejsce między spisami zespołów a przewodnikami po zasobie archiwum. Uznano przy tym, że przygotowując informatory, należy wykorzystywać zasady stosowane od początku lat 80 . XX w. przy wydawaniu drukiem przewodników po zasobie archiwum ${ }^{14}$, zaznaczając jednak, że nie wszystkie sformułowane wówczas wytyczne powinny być stosowane przy opracowaniu informatorów. Zalecano, aby części obowiązkowe w przewodnikach: „Przedmowa” i „Wstęp” zostały w informatorach zastąpione przez ogólny wstęp do wydawnictwa. W opisach kolejnych zespołów (zbiorów) archiwalnych miały być pomijane informacje o aktotwórcy i miejscu przechowywania oraz opis dziejów zespołu.

Zgodnie z zaleceniami z czerwca 2000 r. tytuły kolejnych informatorów powinny zawierać dwa elementy: nazwę archiwum i nazwę opracowania, choć nie narzucono wspólnego dla wszystkich opracowań schematu umieszczania w tytule tych dwóch elementów ${ }^{15}$. Jako przykład podano jeden wariant - „Archiwum Państwowe w «X». Informator o zasobie”. W założeniu zawartość każdego informatora ma stanowić opis

12 M. Lewandowska, Sprawozdanie z narady w sprawie opracowania przewodników..., s. 283-284. Do tej grupy należały m.in.: Informator o zasobie archiwalnym [Wojewódzkiego Archiwum Państwowego w Przemyślu], oprac. Z. Konieczny i in., Przemyśl 1979; Informator o zasobie archiwalnym [Wojewódzkiego Archiwum Państwowego w Kielcach], oprac. zbior. pod kier. S. Marcinkowskiego, Kielce 1980; Informator archiwalny Wojewódzkiego Archiwum Państwowego w Rzeszowie, oprac. zesp. Z. Barnak i in., Rzeszów 1982.

13 Pismo Naczelnego Dyrektora Archiwów Państwowych z 6 czerwca 2000 r. ...

${ }_{14}$ Pismo okólne nr 4 Naczelnego Dyrektora Archiwów Państwowych z 12 czerwca 1982 r. w sprawie wprowadzenia wskazówek metodycznych dotyczacych opracowywania przewodników po zasobie archiwum i załączone do niego Wskazówki metodyczne do opracowania przewodnika po zasobie archiwum, zob.: Zbiór przepisów archiwalnych wydanych przez Naczelnego Dyrektora Archiwów Państwowych w latach 1952-2000, wyb. i oprac. M. Tarakanowska, E. Rosowska, Warszawa 2001, s. 478-497.

15 Charakterystyka informatorów na podstawie wspomnianych wcześniej zaleceń, zob. Zalecenia dotyczace opracowania informatora... 
zasobu samodzielnego archiwum. Dopuszczano jednak sytuację, w której osobno publikowano by tomy dla „centrali” i oddziałów terenowych.

Schemat zawartości informatorów przewiduje układ dziesięciu elementów. Poza stroną tytułową są to kolejno: spis treści, wstęp, wykaz skrótów, wykaz skrótów bibliograficznych, prezentacja zasobu archiwum, bibliografia, indeks osób, indeks geograficzny, streszczenia obcojęzyczne. Najważniejsze z nich - z punktu widzenia informacyjnego - są w zaleceniach omówione dokładniej. Spis treści ma szczegółowo oddawać strukturę podziału wydawnictwa na rozdziały i podrozdziały. We wstępnie należy przedstawić cel, przedmiot i zakres opracowywanego informatora, scharakteryzować jego budowę i zasady opracowania. Ma się w nim również znaleźć: krótka informacja o samym archiwum, opisowa charakterystyka zasobu, prezentacja zasad udostępniania materiałów archiwalnych (obejmująca wszystkie zespoły, także te, które nie zostały w pełni opracowane), terminy korzystania z pracowni naukowej i reprograficznej, informacje o sposobie korzystania z pomocy archiwalnych, zamawiania poszczególnych jednostek oraz powoływania się (cytowania) na archiwalia. Bibliografia powinna zawierać jedynie wybór ważniejszych i najnowszych publikacji. Indeksy powinny odnosić się do części informatora, która prezentuje zasób archiwum, a numery w nich zawarte - do pozycji opisu w zrębie głównym tomu (nie do strony). Obowiązkowo w informatorach mają się pojawiać streszczenia w języku angielskim, choć dopuszcza się publikowanie streszczeń w innych językach. Ich zawartością mają być wybrane informacje ze wstępu do wydawnictwa, przede wszystkim ogólna charakterystyka zasobu, zasady i terminy korzystania.

Spośród części informatorów najdokładniej opisano dwie: zrąb główny informatora oraz charakterystyki wyszukiwawcze. W części zawierającej opis zasobu archiwum przewiduje się wyodrębnienie piętnastu głównych działów. Są to: 1) akta miast, cechów i gmin; 2) administracja państwowa ogólna; 3) administracja państwowa specjalna; 4) instytucje wymiaru sprawiedliwości; 5) administracja gospodarcza; 6) organizacje gospodarcze, przedsiębiorstwa i zakłady; 7) banki, instytucje kredytowe i ubezpieczeniowe; 8) spółdzielczość; 9) akta instytucji i stowarzyszeń społecznych, związków zawodowych; 10) partie polityczne i organizacje młodzieżowe; 11) akta wyznaniowe, w tym akta metrykalne i akta stanu cywilnego; 12) instytucje kulturalne, oświatowe i naukowe, w tym szkolnictwo; 13) archiwa rodowe i prywatne; 14) zbiory, kolekcje i spu- 
ścizny; 15) mikrofilmy. Działy 1), 2), 12) mają być wewnątrz podzielone chronologicznie na poddziały do 1918 r., z lat 1918-1939, 1939-1945, 1945-1989 i po 1989 r., natomiast części od 6) do 10) - na podgrupy do i po 1945 r. Wśród mikrofilmów należy wymienić zarówno kopie materiałów archiwalnych z prezentowanego archiwum, jak i z archiwaliów pochodzących z innych placówek gromadzących, przechowujących, opracowujących i udostępniających narodowy zasób archiwalny. Uznano, że przedmiotem jednostkowych opisów zamieszczanych w informatorach powinny być osobne całości archiwalne, przede wszystkim zespoły, choć także - o ile wchodziły w skład zasobu archiwum - zbiory i kolekcje. Co ważne, w informatorach planowano publikować opisy wszystkich zespołów (zbiorów) archiwalnych, bez względu na stan ich opracowania.

Struktura pojedynczej charakterystyki wyszukiwawczej przewiduje dziewięć elementów. Pierwszym z nich ma być numer opisu, czyli cyfra arabska odpowiadająca kolejnej pozycji zespołu (zbioru) w informatorze. Drugim - tytuł zespołu i jego numer w ewidencji zasobu archiwum państwowego. Trzeci element opisu mają stanowić daty skrajne zespołu (wyznaczone latami powstania najstarszej i najnowszej jednostki archiwalnej w zespole), a czwarty - jego rozmiary: liczba jednostek archiwalnych i metrów bieżących zajmowanych przez materiały archiwalny. Piąty element opisu powinien zawierać charakterystykę zawartości zespołu i zwięzły opis części, z których się składa, szósty - informacje o języku (językach) występujących w materiałach. Wymaga się przy tym, aby w charakterystyce wyszukiwawczej uszeregować języki wg częstotliwości występowania (od najpowszechniej występującego). Siódmy punkt w opisie jest informacją o stanie zmikrofilmowania dokumentacji, ósmy zawiera listę pomocy informacyjno-wyszukiwawczych, które dla zespołu opracowano. Dziewiąty ma zestawiać bibliografię dotyczącą opisywanej całości archiwalnej. Zakładano, że będą tu umieszczane skrócone wersje opisów bibliograficznych najważniejszych i najnowszych publikacji dotyczących danego zespołu (zbioru) archiwalnego. W sytuacji, w której informator jest dziełem zbiorowym, nakazywano, aby każda charakterystyka wyszukiwawcza zaopatrzona była w inicjały autora opisu. Spis inicjałów ma wówczas być integralnym elementem informatora i być wydrukowany na stronie redakcyjnej tomu.

Newralgicznym - z informacyjnego punktu widzenia - elementem opisu zespołu (zbioru) archiwalnego jest charakterystyka jego zawartości. 
Szkoda, że zasady jej formułowania określone są w wytycznych niezbyt precyzyjnie. Poza stwierdzeniem, że jest konieczna i ma jej towarzyszyć opis części, z których jest zbudowany zespół (zbiór), zaznaczono jedynie, że „informacje tego typu powinny być mniej szczegółowe, niż jest to wymagane $\mathrm{w}$ przypadku przewodnika po zasobie archiwum państwowego"16.

Publikacje należące do analizowanej grupy nie są zestandaryzowane. Nie wynika to tylko z faktu, na który archiwiści zwracają uwagę od lat, czyli specyfiki zasobów poszczególnych archiwów. W dużej mierze różnorodność informatorów jest wynikiem niejednoznacznego brzmienia i ogólności wytycznych z czerwca 2000 r. Można nawet zaryzykować stwierdzenie, że - mimo widocznych różnic - wszystkie informatory poddane analizie są zgodne z Zaleceniami dotyczq̨cymi opracowania informatora o zasobie archiwum państwowego. Wytyczne umożliwiają przecież wydawanie informatorów albo dla archiwum państwowego wraz z jego oddziałami, albo osobnych publikacji dla centrali i każdego z jej terenowych oddziałów. Wskazują wspólne elementy, które muszą znaleźć się w tytule informatora, ale dają możliwość dowolnego ich uszeregowania. Podział na części informatora i ich kolejność jest tylko przykładem, a schemat struktury zrębu głównego (opisu zasobu) - jedynie propozycją. Zresztą w wytycznych wprost nakazuje się dostosować go do specyfiki archiwum bądź zastąpić podziałem przyjętym w bazie SEZAM ${ }^{17}$. Powierz-

${ }^{16}$ Zalecania dotyczace opracowania informatora... Przywoływane tu wytyczne rzeczywiście obszernie charakteryzowały przewodnikowy opis zawartości zespołów. Miał on uwzględniać informacje o treści i rodzajach materiałów, wyszczególnione w kolejności wynikającej z inwentarza archiwalnego z „uwypukleniem tytułów grup rzeczowych lub nazw komórek organizacyjnych". Tytułom wszystkich opisanych w ten sposób serii miał towarzyszyć przedział sygnatur jednostek archiwalnych. Wskazywać na wszystkie archiwalia wydzielone z zespołu i dodane do niego na drodze sukcesji. Zwracano także uwagę na „adekwatność przekazywanej informacji do treści” archiwaliów i nakłaniano do precyzyjnego formułowania deskryptorów. Por. Wskazówki metodyczne do opracowania przewodnika po zasobie archiwum, [w:] Zbiór przepisów archiwalnych wydanych przez Naczelnego Dyrektora Archiwów Państwowych..., s. 483.

17 „Podany schemat należy traktować jako przykładowy. Autorzy informatora muszą dostosować go do specyfiki zasobu danego archiwum. Jako przykładowy schemat podziału zasobu można przyjąć też układ zastosowany w bazie danych SEZAM. Układ zespołów i zbiorów powinien być zastosowany w odniesieniu do AP (centrali) i oddzielnie dla każdego z oddziałów terenowych. W ramach podanego układu należy tworzyć podgrupy rzeczowe i chronologiczne". Zalecenia dotyczace opracowania informatora... 
chowna charakterystyka zasad przygotowania opisu zawartości zespołów archiwalnych pozwala ich autorom na pełną swobodę wyboru zarówno konstrukcji opisu, jak i języka wyszukiwawczego. Nakazują zaopatrywanie informatora w indeks geograficzny, podczas gdy indeks osób ma być w nim umieszczany w sytuacjach uzasadnionych specyfiką zasobu. Zobowiązują do umieszczania w informatorach streszczeń najważniejszych dla użytkowników informacji w języku angielskim, choć dopuszczają - w zależności od potrzeb - zaopatrywanie wydawnictw w podobne streszczenia także w innych językach. Najprecyzyjniej w zaleceniach podano zasady umieszczania w informatorze danych o autorach ${ }^{18}$.

Wymienione wyżej różnice $\mathrm{w}$ konstrukcji informatorów tylko z pozoru są błahe. W rzeczywistości mogą utrudniać proces wyszukiwania danych, a w przypadku mało doświadczonych użytkowników - uniemożliwiać uzyskanie pełnych, trafnych odpowiedzi. Nawet brak zestandaryzowanego tytułu informatorów może sprawić, że będą one „niewidoczne” dla potencjalnych użytkowników, a brak wiedzy o nich zmusi badaczy do wykorzystania bardziej zaawansowanych technik wyszukiwawczych.

Rezygnacja z indeksu osób w części informatorów ${ }^{19}$, połączenie go $\mathrm{z}$ indeksem geograficznym ${ }^{20}$ i rzeczowym ${ }^{21} \mathrm{~W}$ naturalny sposób wydłuża proces wyszukiwania danych. Natomiast streszczenia najważniejszych informacji potrzebnych do prowadzenia kwerendy w archiwum publikowane tylko w jednym języku - nawet angielskim - ograniczają możliwości badaczy-cudzoziemców.

Poważniejsze zagrożenie niesie zasygnalizowana wyżej powierzchowna charakterystyka zasad przygotowania opisów zawartości zespołów archiwalnych. Z tego powodu charakterystyki wyszukiwawcze, nawet w tych samych informatorach, znacznie się od siebie różnią. W zdecydowanej większości przypadków składają się one z listy słów kluczowych.

18 „[... [jeśli informator jest dziełem samodzielnym lub zespołu maksymalnie trzech osób, ich nazwiska umieszczone zostają na stronie tytułowej. W przypadku opracowania zbiorowego, spis autorów (w kolejności alfabetycznej), wraz z inicjałami umieszczonymi w nawiasach kwadratowych, podany jest na stronie zatytułowej, zaś na stronie tytułowej figuruje nazwisko redaktora (praca zbiorowa pod redakcją «X»)", Zalecenia dotyczace opracowania informatora...

${ }_{19}$ M.in. pierwsze wydanie informatora dla AP w Białymstoku, Kaliszu, Koszalinie, Lesznie, Piotrkowie Trybunalskim.

${ }^{20}$ Informator łowicki.

21 Drugie wydanie informatora łomżyńskiego. 
Rzadko opisują zawartość serii, na które w czasie opracowania dzielony jest każdy zespół archiwalny. Niezbyt często deskryptory odnoszą się do treści materiałów archiwalnych. Najczęściej są terminami określającymi rodzaje dokumentów tworzących zespół, a tego rodzaju informacje - by pozwoliły zorientować się w zawartości archiwaliów - wymagają od użytkowników dużego doświadczenia badawczego. Np. w informatorze AP w Katowicach, w opisie zespołu Prezydium Dzielnicowej Rady Narodowej [dalej: DRN] w Katowicach Śródmieściu Załężu, charakterystyka zawartości zespołu to: „Regulamin DRN, wykazy i kwestionariusz radnych, protokoły sesji, regulamin Prezydium, plany pracy, sprawozdania z działalności, protokoły posiedzeń Prezydium"22. 0 ile można bez większego problemu przyjąć, że kwestionariusze radnych zawierają ich dane osobowe, o tyle, by wiedzieć, jakie informacje znajdują się w sprawozdaniach z działalności DRN, trzeba najpierw wiedzieć, jakie sprawozdanie w danym czasie DRN wytwarzały i jakie kwestie wchodziły w zakres ich kompetencji.

Nie wszystkie różnice między analizowanymi informatorami wynikają z możliwości dowolnej interpretacji zaleceń. Część z nich jest przejawem inicjatywy podejmowanej przez autorów bądź wydawców. Niektóre - z informacyjnego punktu widzenia - należy ocenić pozytywnie, inne - za niezbyt szczęśliwe. Do pierwszej grupy należy na pewno opublikowanie przez kilka archiwów obcojęzycznych tłumaczeń wstępów w miejsce streszczeń najważniejszych dla korzystających z informacji oraz umieszczenie ich w informatorach od razu po polskojęzycznym wstępie (nie na końcu publikacji) ${ }^{23}$. Zdecydowana większość archiwów zaopatrzyła swoje wydawnictwa także w streszczenia inne niż anglojęzyczne ${ }^{24}$. Powszechnie - obok języka angielskiego - używanym językiem streszczeń lub tłumaczeń wstępów jest niemiecki ${ }^{25}$. Do wszystkich informatorów

22 Archiwum Państwowe w Katowicach. Informator o zasobie archiwalnym, oprac. zbior. pod red. P. Matuszka, Warszawa 2007, s. 194-195.

${ }^{23}$ Por. informatory dla archiwów w Kaliszu, Katowicach i jego oddziałów, Przemyślu.

${ }^{24} \mathrm{~W}$ pierwszym wydaniu informatora AP w Białymstoku i w informatorze z Piotrkowa Trybunalskiego są streszczenia tylko po angielsku. W drugim wydaniu informatora białostockiego oraz w informatorze jego łomżyńskiego oddziału streszczeń nie ma wcale.

25 Np. w informatorach przygotowanych przez archiwa w Elblągu, Kaliszu, Katowicach z oddziałami, Koszalinie, Lesznie, Łowiczu, Olsztynie, Przemyślu. 
katowickiego archiwum dodano tłumaczenie wstępu w języku czeskim, a do przemyskiego - ukraińskim.

Pozytywnie należy ocenić rozbudowanie informatorów o różne, pożyteczne elementy treści, których zalecenia z czerwca 2000 r. nie przewidywały. W wydawnictwie przemyskim w osobnej części podane zostały materiały archiwalne przechowywane w muzeach ziemi przemyskiej (Muzeum w Jarosławiu Kamienica Orsettich; Muzeum Narodowe Ziemi Przemyskiej w Przemyślu; Muzeum w Przeworsku Zespół PałacowoParkowy ${ }^{26}$. Informator piotrkowski zawiera aneks, zestawiający zespoły archiwalne twórców działających na obecnym obszarze prac AP w Piotrkowie Trybunalskim, przechowywane jednak w zasobie łódzkiego archiwum państwowego. Do wydawnictwa AP w Elblągu z siedzibą w Malborku dołączono wykaz przechowywanych ksiąg stanu cywilnego, zawierający informacje także o miejscu przechowywania ksiąg w innych archiwach na terenie kraju oraz w Niemczech. Informatory oddziałów w Cieszynie, Pszczynie, Gliwicach i Łowiczu zaopatrzono w alfabetyczny wykaz nazw zespołów i zbiorów archiwalnych, które mogą w tych wydawnictwach odgrywać rolę indeksów haseł korporatywnych.

Szkoda, że w kilku przypadkach zrezygnowano z wydzielania we wstępach części opisujących cel, przedmiot i zakres informatora, zasady jego opracowania, historię archiwum i opisową charakterystykę jego zasobu czy zasady korzystania z materiałów archiwalnych ${ }^{27}$. Co prawda zalecenia nie zmuszają do wprowadzenia takiego podziału, należy jednak uznać, że taka systematyzacja treści wstępów jest jak najbardziej korzystna z informacyjnego punktu widzenia. Zdarza się, że podział wstępu na części nie jest odnotowany w spisie treści lub słabo wyróżniony w tekście. Na przykład w informatorze olsztyńskim cały wstęp jest w jednym bloku, bez wyróżnień. W pierwszym wydaniu informatora AP w Białymstoku w spisie treści nie zostało m.in. odnotowane streszczenie w języku angielskim.

${ }^{26}$ Zastosowano tu rozwiązanie sprawdzone w przeszłości. W wydanym w końcu lat 70. XX w. informatorze znalazł się dział „II. Archiwalia w muzeach województwa przemyskiego (w Jarosławiu, Przemyślu, Przeworsku)", zob. Informator o zasobie archiwalnym [Wojewódzkiego Archiwum Państwowego w Przemyślu], oprac. Z. Konieczny i in., Przemyśl 1979.

27 Tak było w przypadku Elbląga, Kalisza, drugiego wydania informatora dla oddziału w Łomży. 
Niewielki wpływ na wartość informacyjną analizowanych publikacji ma, naszym zdaniem, niemal powszechna rezygnacja z wykazu skrótów bibliograficznych ${ }^{28}$ oraz pomijanie pól z bibliografią w opisach poszczególnych zespołów zamieszczanych w większości informatorów.

W zaleceniach z 2000 r. zapisane zostały tylko propozycje dotyczące struktury dokumentu. W zasadzie pominięto szeroko pojęte zasady opracowania edytorskiego. Archiwalne pomoce informacyjne powinny z definicji być „przyjazne dla czytelnika”, a więc charakteryzować się przejrzystą konstrukcją. Powinny być czytelnie i estetycznie skomponowane na płaszczyźnie makro- i mikrotypografii, aby służyć sprawnemu przyswajaniu treści z jednoczesnym jej zrozumieniem. Kluczem do osiągnięcia tego celu jest przede wszystkim odpowiednia architektura informacji, rozumiana jako strukturalne projektowanie przestrzeni informacyjnej, służące ułatwieniu kompletowania informacji i udostępnianiu jej użytkownikom. W tym kontekście ważna jest przede wszystkim konstrukcja przekazu, ale również i odpowiednio wykorzystany aparat narzędziowy typografii ${ }^{29}$.

Podstawowe kryteria doboru narzędzi typografii wyznacza grupa docelowa odbiorców, użyteczność i funkcja publikacji. W odniesieniu do wydanych już informatorów nasuwa się kilka refleksji. Wszystkim nadano format B5, co wydaje się uzasadnione tradycją w tym zakresie (dla publikacji naukowych) oraz możliwością lepszego zagospodarowania treści, szczególnie w odniesieniu do opisów jednostkowych zespołów archiwalnych. Takie samo uzasadnienie dotyczy składu jednołamowego, wyjustowanego, chociaż występują już odstępstwa od tego rozwiązania $^{30}$ - wydaje się, że niekorzystne dla długich opisów - i obustronnego justowania.

${ }^{28}$ Wszystkie wydania informatora białostockiego i jego oddziału w Łomży, Kalisz, Katowice i jego oddziały, Koszalin, Leszno, Olsztyn, Piotrków Trybunalski.

${ }^{29}$ Za podstawowe funkcje typografii należy uznać: czytelność, organizację, nawigację i spójność, por. M. Mitchell, S. Wighhtman, Typografia książki. Podręcznik projektanta, Kraków 2012, s. 18-19.

${ }^{30} \mathrm{~W}$ dwóch łamach złożono tekst w dwóch informatorach przeznaczonych dla centrali i łomżyńskiego oddziału AP w Białymstoku. J. Krochmal zaznaczył, że taka forma pierwszego wydania informatora o zasobie AP w Białymstoku została „dobrze przyjęta w środowisku archiwistów", por. J. Krochmal, dz. cyt., s. 259. 
Kolejna uwaga dotyczy zastosowanych krojów i wielkości pisma. $\mathrm{Z}$ reguły dobierano kroje szeryfowe, obok najpopularniejszego jak Times New Roman, chętnie też - relatywnie większe w oczku (przy tym samym stopniu pisma) - z rodziny Baskerville lub Century (Leszno). Wydaje się jednak, że w przypadku tych krojów skład tekstów wprowadzających jest zbyt ścisły, tworzy mało czytelne bloki kolumn na poszczególnych stronach, przy wąskich marginesach. Intencją twórców była z pewnością poprawa czytelności, stąd taki dobór stopnia pisma, ale bez zachowania odpowiednich proporcji w stosunku do interlinii i marginesów efekt ten nie został w pełni osiągnięty. Wyraźnie widać, że w odniesieniu do zasadniczej części opracowań, czyli opisu zespołów, przy rosnącej objętości tomów - redaktorzy wybranych z nich - zdroworozsądkowo decydowali się na zmniejszenie stopnia pisma ${ }^{31}$. I przy odpowiednich proporcjach efekt czytelności był nadal właściwy.

Większość informatorów ma szyte bloki i opatrzona została w twardą okładkę ${ }^{32}$. Takie rozwiązania korespondują z ich objętością (w kilku przypadkach to ponad 600 stron) oraz trwałością, przy założeniu intensywnego użytkowania i przechowywania w podręcznych księgozbiorach. Barwa i rodzaj papieru w omawianym przypadku jest drugorzędna, nie należy jednak zapominać o potrzebie trwałości materiału i o tym, że idealna biel papieru sprawia, że lśni bardzo intensywnie i może przeszkadzać w czytaniu. Do długich jednostajnych tekstów lepsze są papiery z mniejszym współczynnikiem bieli. Jeżeli do informatora włączano ilustracje w formie aneksu w bloczku, to w większości przypadków wykorzystywano papier kredowy o bardzo dużym współczynniku bieli, większej gramaturze, wielokrotnie powlekany, z połyskiem, choć nie było to bezwzględną regułą.

We wczesnych projektach firmowanych przez Naczelną Dyrekcję AP odznaczających się co prawda dużą konsekwencją - wyraźnie zabrakło większej swobody w korzystaniu z wyróżnień. W tych informatorach przyjęto dość sztywną interpretację zaleceń z 2000 r. Widać to na przykładzie poszczególnych opisów zespołów. Informacje w nich zawarte, występujące w ustalonym porządku, opatrzono tylko ciągłą numeracją. Jest to zrozumiałe, ale też dość schematyczne i jednostajne. Natomiast przy

${ }^{31}$ Por. np. informator AP w Przemyślu.

32 Wyjątkiem są wszystkie informatory białostockie. 
zastosowaniu wyróżnień, takich jak pogrubienia, wcięcia akapitowe, kursywa, efekt jest dużo lepszy - poprawia czytelność i ułatwia korzystanie. Dobrym rozwiązaniem jest też umiejętne łączenie krojów szeryfowych i bezszeryfowych. Użytkownik po rodzaju wyróżnień szybciej spostrzega wybrany element opisu. Są one też sposobem na zaznaczenie poziomu szczegółowości informacji, co w odniesieniu do indeksów wydaje się niezbędnym narzędziem do zwiększania efektywności w przetwarzaniu informacji. Co ciekawe, ta uwaga nie dotyczy spisów treści, które właśnie poprzez różnego rodzaju wyróżnienia dobrze oddają układ publikacji i zasadę szeregowania wewnętrznego (tj. rzędy tytułów, wypunktowania, wcięcia, wersaliki, pogrubienia czy kursywa) ${ }^{33}$. Nigdzie nie zastosowano koloru jako wyróżnika, co może być determinowane czynnikami ekonomicznymi.

Wśród ważnych elementów ułatwiających nawigację w publikacjach naukowych, a zwłaszcza o charakterze pomocy informacyjnych, należy wymienić żywą paginę. Niestety, nie wszyscy pamiętali o tym praktycznym i prostym rozwiązaniu ${ }^{34}$. W niektórych pozycjach nieumiejętnie zastosowana żywa pagina nie do końca spełniła swoją rolę, np. tam, gdzie wstawiano w niej tylko określenia „wstęp”, a występuje w tej części podział wewnętrzny, który także można było uwzględnić. Podobnie nie do końca trafione było użycie określenia w całym zrębie głównym „zasób archiwum" (strona parzysta), a tylko na nieparzystej - tytułu działu pierwszego rzędu ${ }^{35}$.

Już po pobieżnym przeglądzie widać, że świadomość typograficzna twórców informatorów rośnie, lecz nadal dominuje posługiwanie się schematami i przyzwyczajeniami. Przy tworzeniu tego typu opracowań najwyraźniej w sposób bardzo ograniczony wykorzystywane są możliwości, jakie daje dziś oprogramowanie do projektowania i łamania publikacji. Idealnym rozwiązaniem byłby więc naturalny mariaż tradycji, ekonomii ze świadomością stale rosnącego potencjału technologicznego. Pamiętać przy tym trzeba, że dobrze dobrana forma nie tylko oddaje

${ }^{33}$ Konkretne wskazówki i rozwiązania zawiera m.in. praca: A. Wolański, Edycja tekstów. Praktyczny poradnik. Książka. Prasa. WWW, Warszawa 2008.

34 Brak ich w pierwszych wydawnictwach łomżyńskim i białostockim, także w informatorze dla łowickiego oddziału AP w Warszawie.

35 Por. np. informatory z Olsztyna, Leszna, Pszczyny czy Cieszyna. 
właściwie treść, ale też ułatwia i przyspiesza korzystanie z publikacji i przeszukiwanie zawartych w niej informacji. Właściwie przygotowane edycje informatorów drukowanych są ciągle niezagrożone, ponieważ alternatywna forma elektroniczna nie zawsze umożliwia pełne i czytelne przeszukiwanie oraz zaspokojenie potrzeb informacyjnych potencjalnych użytkowników. Pozwala jednak na wykorzystanie, bez konsekwencji ekonomicznych, znacznie szerszej palety narzędzi typografii. Z pewnością jednak przyszłość przyniesie i w tej materii nieuniknione zmiany.

Analiza informatorów wydawanych przez archiwa państwowe podległe Naczelnej Dyrekcji AP od czerwca 2000 r. pokazuje, że nie udało się osiągnąć pełnej standaryzacji tego typu pomocy informacyjno-wyszukiwawczych. Wydane wówczas zalecenia są zbyt ogólne i niejednoznaczne, co jest jedną z przyczyn porażki zamierzeń unifikacji założonej przez centralną administrację archiwalną. Zresztą twórcy i wydawcy poszczególnych pomocy z własnej inicjatywy zmieniali ich budowę. Wprowadzane przez nich modyfikacje nie zawsze są korzystne. Rzadko także wydawcy informatorów świadomie korzystali z narzędzi typograficznych, które mogą zwiększyć informacyjną użyteczność tych pomocy. To wszystko spowodowało, że omawianym informatorom daleko do ideału.

Z niedostatków cechujących informatory przygotowywane w oparciu o zalecenia z 2000 r. zdają sobie sprawę kolejni wydawcy. We wstępie do ostatnio opublikowanego informatora AP w Bydgoszczy napisano nawet, że przy jego edycji świadomie „zrezygnowano z przyjętego w ostatnich latach sztywnego modelu tego typu opracowań wybranego już przez kilka informatorów"36. Rzeczywiście, bydgoski informator ma strukturę odbiegającą od wszystkich wcześniejszych edycji. Co prawda podzielono go na dwie główne części, w których osobno scharakteryzowany został zasób centrali i oddziału (w przypadku AP w Bydgoszczy mieszczącego się w Inowrocławiu) ${ }^{37}$, jednak wstęp do informatora bydgoskiego jest obszernym studium nad historią archiwum i jego zasobu. Większość

36 Informator o zasobie archiwalnym Archiwum Państwowego w Bydgoszczy, oprac. S. Błażejewski, M. Dereszyńska-Romaniuk, L. Wakuluk, Bydgoszcz-Warszawa 2013, s. 11.

${ }^{37}$ Co umożliwiają zalecenia z 2000 r. i jak postąpiono choćby w przypadku informatora AP w Olsztynie. 
części wydzielonych w zrębie głównym i zawierających opisy zespołów określonego typu instytucji zaopatrzono we wspólne dla nich charakterystyki informujące o podstawach funkcjonowania i organizacji twórców, ich kompetencjach i zasięgu terytorialnym. Wydawcy świadomie korzystali też z narzędzi typograficznych przy składzie charakterystyk wyszukiwawczych. Wcięcia akapitowe, pogrubienia tytułów zespołów, różne kroje i wielkość znaków sprawiają, że wyszukiwanie informacji jest łatwiejsze.

Podjęte przez twórców i wydawców informatora bydgoskiego działania zwiększają jego walory informacyjne i pokazują, że istnieje potrzeba dalszej pracy nad modelem informatora o zasobie archiwalnym. Jednak czy - w kontekście budowania spójnego systemu informacji archiwalnej takie partykularne działania przyniosą oczekiwany efekt? Wydaje się, że nie. Związek między standaryzacją publikowanych tradycyjnie archiwalnych pomocy informacyjnych i użytecznością w wyszukiwaniu informacji w zasobach archiwów zdaje się potwierdzać wyniki prowadzonych ostatnio badań nad tzw. efektem Google, czyli wpływem dostępności informacji na sposób, w jaki je zapamiętujemy. Jeden z eksperymentów myślowych zaprojektowany w trakcie tych prac przez Betsy Sparow (Columbia University) i dwójkę jej współpracowników: Daniela M. Wegnera (Harvard) i Jenny Liu (University of Wisconsin) pozwolił dostrzec, że uczestnicy badania nie podejmowali wysiłku, by zapamiętać informacje, jeśli byli pewni, że w przyszłości odnajdą dane ponownie ${ }^{38}$.

Pewność sprawnego wyszukania informacji użytkownicy informatorów uzyskaliby, gdyby faktycznie nadano im jednakową strukturę, a w każdym z nich zastosowano podział zrębu głównego na te same działy, wszystkie charakterystyki wyszukiwawcze byłyby zbudowane z tych samych pól, a informacja o zawartości zespołu archiwalnego miałaby ujednoliconą strukturę i sporządzana byłaby zawsze za pomocą tego samego języka wyszukiwawczego. Standaryzacją należałoby objąć też środki typograficzne zwiększające łatwość identyfikacji informacji. Tylko w takim przypadku użytkownicy archiwów mogliby, należące do tej grupy pomoce informacyjne, uznać za w pełni efektywne narzędzie

38 P. Cohen, Internet Use Affects Memory, Study Finds. „The New York Times” [online] July 14, 2011 [dostęp 31 października 2014]. Dostępny w World Wide Web: http://www. nytimes.com/2011/07/15/health/15memory.html?_r=1. 
wyszukiwania informacji. Oczywiście przy założeniu, że taka koncepcja informatora będzie powszechnie akceptowana i realizowana.

\section{Bibliografia}

Archiwum Główne Akt Dawnych w Warszawie. Informator o zasobie archiwalnym, oprac. zbior. pod red. Doroty Lewandowskiej, Warszawa 2008.

Archiwum Główne Akt Dawnych. Informator o zasobie, oprac. zbior. pod red. Teresy Zielińskiej, Warszawa 1992.

Archiwum Państwowe m.st. Warszawy Oddział w Mławie. Informator o zasobie archiwalnym, oprac. Andrzej Grochowski, Monika Kowzon-Świtalska [online]. Warszawa: Archiwum Państwowe w Warszawie, 2010, 333 s. [dostęp 31 października 2014]. Dostępny w World Wide Web: http://www.warszawa.ap.gov.pl/publikacje/informator-mlawa.pdf.

Archiwum Państwowe w Katowicach. Informator o zasobie archiwalnym, oprac. zbior. pod red. Piotra Matuszka, Warszawa 2007.

Cohen Patricia, Internet Use Affects Memory, Study Finds. „The New York Times” [online] July 14, 2011 [dostęp 31 października 2014]. Dostępny w World Wide Web: http://www.nytimes.com/2011/07/15/health/15memory. html?_r=1.

Degen Robert, Przegląd piśmiennictwa archiwistycznego (część VI), „Archiwista Polski" 2004, nr 2, s. 102-109.

Degen Robert, Przegląd piśmiennictwa archiwistycznego (część XII), „Archiwista Polski" 2005, nr 4, s. 97-105.

Gołembiowski Maciej, System informacji archiwalnej, Warszawa-Łódź 1985.

Informator archiwalny Wojewódzkiego Archiwum Państwowego w Rzeszowie, oprac. zesp. Zofia Barnak i in., Rzeszów 1982.

Informator o zasobie archiwalnym [Archiwum Akt Nowych $w$ Warszawie], oprac.

E. Kołodziej, współpr. W. Bieńkowska, B. Nowożycki, t. 1-2, Warszawa 2009. Informator o zasobie archiwalnym [Wojewódzkiego Archiwum Państwowego w Przemyślu], oprac. Zdzisław Konieczny i in., Przemyśl 1979.

Informator o zasobie archiwalnym [Wojewódzkiego Archiwum Państwowego w Kielcach], oprac. zbior. pod kier. Stanisława Marcinkowskiego, Kielce 1980. 
Informator o zasobie archiwalnym Archiwum Państwowego w Bydgoszczy, oprac. Stanisław Błażejewski, Melania Dereszyńska-Romaniuk, Lidia Wakuluk, Bydgoszcz-Warszawa 2013.

Informator o zasobie Archiwum Państwowego w Zielonej Górze, red. nauk. Zbigniew Bujkiewicz, Wojciech Strzyżewski, Zielona Góra 2003.

Krochmal Jacek, Zasady opracowania informatora o zasobie archiwalnym. Na marginesie publikacji „Informator o zasobie archiwalnym”, oprac. Jerzy Szumski, Białystok 2000, Archiwum Państwowe w Białymstoku, ss. 279, „Archeion” t. 104: 2002, s. 257-259.

Lewandowska Maria, Sprawozdanie z narady w sprawie opracowania przewodników po zasobach archiwów, „Archeion” t. 64: 1976, s. 283-284.

Mitchell Michael, Wighhtman Susan, Typografia książki. Podręcznik projektanta, Kraków 2012.

Ohryzko-Włodarska Czesława, Pomoce informacyjne w archiwach. Stan obecny i perspektywy na przyszłość, „Archeion” t. 68: 1979, s. 87-97.

Pismo Naczelnego Dyrektora Archiwów Państwowych z 6 czerwca 2000 r. w sprawie zaleceń dotyczących opracowania informatora o zasobie archiwum państwowego (wraz z Zaleceniami dotyczacymi opracowania informatora o zasobie archiwum państwowego) [online]. Warszawa: Naczelna Dyrekcja Archiwów Państwowych, 2000, 6 s. [dostęp 31 października 2014]. Dostępny w World Wide Web: http://www.archiwa.gov.pl/images/stories/ file/pdf/Pismo_6_2000.pdf.

Pismo okólne nr 4 Naczelnego Dyrektora Archiwów Państwowych z 12 czerwca 1982 r. w sprawie wprowadzenia wskazówek metodycznych dotyczacych opracowywania przewodników po zasobie archiwum (wraz z Wskazówkami metodycznymi do opracowania przewodnika po zasobie archiwum), [w:] Zbiór przepisów archiwalnych wydanych przez Naczelnego Dyrektora Archiwów Państwowych w latach 1952-2000, wyb. i oprac. Maria Tarakanowska, Ewa Rosowska, Warszawa 2001, s. 478-497.

Ryszewski Bohdan, Przegląd oraz systematyka pomocy archiwalnych polskich i obcych opublikowanych w ostatnim ćwierćwieczu, „Archeion” t. 87: 1990, s. 4-21.

Wolański Adam F., Edycja tekstów. Praktyczny poradnik. Książka. Prasa. WWW, Warszawa 2008. 
Aneks

Chronologiczny wykaz informatorów po zasobach archiwów wydanych przez archiwa państwowe, opracowanych zgodnie z zaleceniami Naczelnego Dyrektora Archiwów Państwowych z 6 czerwca 2000 r.

1. Informator o zasobie archiwalnym [Archiwum Państwowego w Białymstoku], oprac. Jerzy Szumski, Białystok 2000.

2. Informator o zasobie archiwalnym [Archiwum Państwowe w Białymstoku. Oddział $w$ Łomży], oprac. Leszek Kocoń, Białystok 2000.

3. Archiwum Państwowe w Elblagu z siedziba w Malborku. Informator o zasobie archiwalnym, oprac. Arkadiusz Wełniak, Warszawa 2003.

4. Archiwum Państwowe w Kaliszu, Informator o zasobie archiwalnym, oprac. Grzegorz Waliś, Warszawa 2004.

5. Archiwum Państwowe w Koszalinie. Informator o zasobie archiwalnym, oprac. Waldemar Chlistowski, Warszawa 2005.

6. Archiwum Państwowe w Lesznie. Informator o zasobie archiwalnym, oprac. Barbara Ratajewska, Marcin Kapała, Warszawa 2005.

7. Archiwum Państwowe w Przemyślu. Informator o zasobie archiwalnym, oprac. Elżbieta Laska, Warszawa-Przemyśl 2007.

8. Archiwum Państwowe w Piotrkowie Trybunalskim. Informator o zasobie archiwalnym, oprac. Piotr Głowacki, Aleksy Piasta, Piotr Zawilski, Warszawa 2007.

9. Archiwum Państwowe w Katowicach. Informator o zasobie archiwalnym, oprac. zbior. pod red. Piotra Matuszka, Warszawa 2007.

10. Archiwum Państwowe w Olsztynie. Informator o zasobie archiwalnym, oprac. Mariusz T. Korejwo, Warszawa 2007.

11. Archiwum Państwowe m.st. Warszawy Oddział w Łowiczu. Informator o zasobie archiwalnym, oprac. Marek Wojtylak, Warszawa 2008.

12. Archiwum Państwowe w Białymstoku. Informator o zasobie archiwalnym, oprac. Tomasz Fiedorowicz, Białystok 2008.

13. Anna Machej, Piotr Matuszek, Archiwum Państwowe w Katowicach Oddział w Cieszynie. Informator o zasobie archiwalnym, Katowice 2009.

14. Piotr Matuszek, Joanna Szczepańczyk, Archiwum Państwowe w Katowicach Oddział w Pszczynie. Informator o zasobie archiwalnym, Katowice 2009.

15. Archiwum Państwowe w Białymstoku Oddział $w$ Łomży. Informator o zasobie archiwalnym, oprac. Danuta Bzura, Białystok 2012. 
16. Archiwum Państwowe w Katowicach - Oddział w Gliwicach. Informator o zasobie archiwalnym, oprac. Izabela Frołow i in., Katowice-Warszawa 2012.

17. Informator o zasobie archiwalnym Archiwum Państwowego w Bydgoszczy, oprac. Stanisław Błażejewski, Melania Dereszyńska-Romaniuk, Lidia Wakuluk, Bydgoszcz-Warszawa 2013.

\section{Directories to archival holdings. An attempt to analyse informative usefulness}

ABSTRACT: In 2000, the General Director of State Archives in Poland issued recommendations how to publish directories to archival holdings. The purpose of these recommendations was to set in Polish archival information system this finding aid (operating between guide to archival holdings and list of funds), to standardize its construction and to increase the importance of this aid in the searching of archival materials. This aim was achieved partially. On the basis of recommendations it is possible to define the term directory to archival holdings, but the standardization of its construction is impossible. Recommendations are susceptible of various interpretations and too general. Moreover, particular state archives have tried to change the construction of directories, but now not all modifications are useful from the archives users' point of view. Editors of directories to archival holdings seldom used typographical tools which could have enhanced the informative usefulness of these finding aids.

KEYWORDS: directory to archival holdings in Poland, typography of archival finding aids. 